\title{
Identification of novel LEPR mutations in Pakistani families with morbid childhood obesity
}

\author{
Robina Khan Niazi ${ }^{1,2,3,4}$, Anette P Gjesing ${ }^{2}$, Mette Hollensted² ${ }^{2}$ Christian Theil Have², Niels Grarup ${ }^{2}$, Oluf Pedersen²,
} Asmat Ullah", Gulbin Shahid ${ }^{3}$, Wasim Ahmad ${ }^{4}$, Asma Gul ${ }^{1}$ and Torben Hansen ${ }^{2 *}$ (D)

\begin{abstract}
Background: Mutations in the genes encoding leptin (LEP), the leptin receptor (LEPR), and the melanocortin 4 receptor (MC4R) are known to cause severe early-onset childhood obesity. The aim of the current study was to examine the prevalence of damaging LEP, LEPR, and MC4R mutations in Pakistani families having a recessive heritance of early-onset obesity.
\end{abstract}

Methods: Using targeted resequencing, the presence of rare mutations in $L E P, L E P R$, and $M C 4 R$, was investigated in individuals from 25 families suspected of having autosomal recessive early-onset obesity. Segregation patterns of variants were assessed based on chip-based genotyping.

Results: Homozygous LEPR variants were identified in two probands. One carried a deletion (c.3260AG) resulting in the frameshift mutation p.Ser1090Trpfs*6, and the second carried a substitution (c.2675C > G) resulting in the missense mutation p.Pro892Arg. Both mutations were located within regions of homozygosity shared only among affected individuals. Both probands displayed early-onset obesity, hyperphagia and diabetes. No mutations were found in LEP and MCAR.

Conclusions: The current study highlights the implication of LEPR mutations in cases of severe early-onset obesity in consanguineous Pakistani families. Through targeted resequencing, we identified novel damaging mutations, and our approach may therefore be utilized in clinical testing or diagnosis of known forms of monogenic obesity with the aim of optimizing obesity treatment.

Keywords: Early-onset obesity, Hyperphagia, Leptin, Leptin receptor, Melanocortin 4 receptor, Monogenic obesity, Pakistani families, Targeted resequencing

\section{Background}

Currently, childhood obesity is considered one of the most serious public health challenges of the twenty-first century. The prevalence of childhood obesity is increasing at an alarming rate, affecting high-income as well as low- and middle-income countries, and the number of overweight and obese children below the age of five is estimated to be 41 million [http://www.who.int/topics/ obesity/en.].

\footnotetext{
* Correspondence: torben.hansen@sund.ku.dk

${ }^{2}$ Novo Nordisk Foundation Center for Basic Metabolic Research, Section of Metabolic Genetics, Faculty of Health and Medical Sciences, University of Copenhagen, Copenhagen, Denmark

Full list of author information is available at the end of the article
}

A strong genetic factor is evident in the etiology of obesity, with heritability estimates ranging from 40 to $70 \%$ [1-3]. Genetic defects disrupting the leptin-melanocortin signaling pathway very often result in severe early-onset obesity and hyperphagia [4-6], and the genes most commonly involved in monogenic forms of obesity are part of this pathway, including leptin $(L E P)$, the leptin receptor (LEPR), and the melanocortin 4 receptor $(M C 4 R)$ [7-9]. Leptin is a 16-KD hormone secreted by white adipocytes which binds to LEPR and regulates energy expenditure through hypothalamic neurons [10]. LEPR is a member of the cytokine receptor family with six isoforms (LEPRa-f), yet, leptin signaling is primarily mediated by the long

(c) The Author(s). 2018 Open Access This article is distributed under the terms of the Creative Commons Attribution 4.0 International License (http://creativecommons.org/licenses/by/4.0/), which permits unrestricted use, distribution, and reproduction in any medium, provided you give appropriate credit to the original author(s) and the source, provide a link to the Creative Commons license, and indicate if changes were made. The Creative Commons Public Domain Dedication waiver (http://creativecommons.org/publicdomain/zero/1.0/) applies to the data made available in this article, unless otherwise stated. 
LEPRb expressed in the hypothalamus [11-13]. The short form is expressed in a number of tissues, including the adrenal gland, kidney, lung, and choroid plexus $[14,15]$. The mutations identified to date in $L E P$ and $L E P R$ are ethnic-specific, and the prevalence of monogenic obesity caused by mutations within these two genes is as high as $>20 \%$ in Pakistani study populations with obesity [16-18].

$M C 4 R$ encodes a 332- amino acid membrane-bound receptor protein [19]. It is expressed in the brain and it influences appetite regulation through interaction with adrenocorticotropic and melanocyte stimulating hormones (MSH) through G proteins [20]. In studies of European populations with severe obesity, the prevalence of heterozygous damaging MC4R mutations is $\sim 6 \%$ and $\sim 2 \%$ in children and adults, respectively [21-23], signifying the different etiologies of childhood and adult obesity.

The disruption of $L E P R$ and leptin deficiency results in severe early-onset hyperphagic obesity with rapid weight increase during the first few months of life $[17,24,25]$. Similarly, during the first year of life, MC4R deficiency has been linked with hyperphagia and increased fat and lean mass, increased linear height, increased bone mineral density and severe early hyperinsulinemia [22, 26], although some of these associations remain controversial [27, 28]. Obesity caused by damaging mutations in LEP and LEPR display an autosomal recessive mode of inheritance while obesity caused by $M C 4 R$ mutations exhibit variable penetrance (recessive or co-dominant) [23].

Genetic sequencing of consanguineous families is an important tool in the identification of deleterious mutations in genes implicated in monogenic forms of obesity [18], as consanguineous families share homozygous regions in their genomes, enabling the identification of deleterious recessive mutations [29]. Due to the high degree of inbreeding in the Pakistani population, homozygous deleterious mutations in LEP, LEPR, and MC4R have been identified in as many as $\sim 30 \%$ of severely obese individuals from consanguineous families [16-18]. In comparison, the prevalence of heterozygous $M C 4 R$ mutations is $3-5 \%$ in Caucasian populations with early-onset obesity [30, 31]. Both LEP and LEPR mutations are rare in Caucasian populations.

The application of next generation sequencing (NGS) provides a powerful method to discover rare disease-causing genetic variants [32]. Therefore, targeted resequencing of $L E P, L E P R$ and $M C 4 R$ was performed to assess the prevalence of damaging mutations within these genes. In total, genetic screening was performed in 25 severely obese probands from Pakistani families of which 14 probands were from families with known consanguineous marriages.

\section{Methods}

\section{Study design}

This family-based study applied a phenotype-driven approach to investigate monogenic causes of obesity in selected Pakistani families with obesity segregating in an autosomal recessive pattern.

\section{Participants}

Twenty-five families, originating from different regions of Pakistan, were recruited and examined at Children Hospital, Pakistan Institute of Medical Sciences (PIMS), Islamabad. Consanguineous marriages were known in 14 of the included families. The selection of the families was based on three criteria: 1) Body mass index (BMI) of probands $\geq 30 \mathrm{~kg} / \mathrm{m}^{2}$; 2) Probands displaying obesity onset before five years of age; and 3) Parents of the probands with $\mathrm{BMI} \leq 25 \mathrm{~kg} / \mathrm{m}^{2}$, consistent with an autosomal recessive mode of inheritance.

\section{Clinical examination}

Through interview sessions, information on age of obesity onset (years), other major chronic disease(s) (if any), metabolic disorder(s) running in the family, eating habits, physical activity, along with obesity-related co-morbidities was recorded. Waist circumference $(\mathrm{cm})$ and height $(\mathrm{cm})$ were measured with a non-elastic plastic tape with the participant standing in an upright position without shoes. Weight $(\mathrm{kg})$, without shoes and in light clothes, was measured to the nearest $0.1 \mathrm{~kg}$ using a digital scale. From these measures, BMI was calculated as the weight in kilograms divided by the square of the height in meters $\left(\mathrm{kg} / \mathrm{m}^{2}\right)$, and using the LMS method [33], a BMI standard deviation score (SDS) was calculated based on a World Health Organization (WHO) reference population [34]. Approximately 3-5 $\mathrm{ml}$ of venous non-fasting blood from affected and un-affected family members were collected in $8.5 \mathrm{ml}$ vacutainer tubes (BD Vacutainer $^{\oplus}$ ACD, Franklin Lakes NJ, USA). Clinical characteristics of the families are presented in Additional file 1.

\section{Genomic DNA extraction}

DNA was extracted from blood samples from 36 affected and 88 unaffected family members. Genomic DNA was primarily extracted using the standard phenol-chloroform method [35], however, in some families, the QIAamp DNA Mini Kit (Qiagen, Germany) was used.

\section{Targeted resequencing}

The probands $(n=25)$ from each family as well as four additional affected individuals (OB2-6, OB4-8, OB4-9, and OB4-10) underwent targeted resequencing. Using a chip-based customized nucleotide probe, targeted resequencing was performed to examine the coding regions 
of $L E P, L E P R$, and MC4R. Methods for target region capture and NGS have previously been extensively described [36]. According to the manufacturer's standard cluster generation and sequencing protocols, the final captured DNA libraries were sequenced using the Illumina HiSeq2000 Analyzers as PE 90 bp reads. Only variants having a minimum mean depth of $20 x$ were included. Identified variants were annotated according to the transcripts 1) LEP: NM_000230; 2) LEPR: NM_002303.5 and 3) MC4R: NM_005912.

\section{Chip genotyping}

Illumina Infinium Human CoreExome Bead Chip (CoreExomeChip) genotyping was performed in 124 individuals from 25 families using Illumina's HiScan system at the laboratory facilities of the Novo Nordisk Foundation Center for Basic Metabolic Research at Symbion, Copenhagen, Denmark. The standard pipeline in Illumina Genome Studio software was used for the genotype calling. The pipeline yielded 551,839 genetic variations, which entered our quality control (QC) pipeline. The Illumina final report was converted to plink format using custom scripts and aligned with the positive strand of the GRCh37 reference.

QC included removal of variants with missing genotypes above $5 \%$ as well as individuals with more than $5 \%$ missing genotype calls, individuals with negative inbreeding, indication of duplicated samples, and discrepancy between genetic identified pedigree and the pedigree obtained from the family. A total of 12 individuals were removed in the QC. We did not remove SNPs deviating from Hardy-Weinberg equilibrium as is otherwise usual, since these variants may be of interest given the specific mode of data sampling.

\section{Homozygosity mapping}

Based on genotyping, runs of homozygosity were determined in each family using the "homozyg" command in PLINK [37].

\section{Results}

In the present study, targeted resequencing data was combined with chip-based genotyping, enabling the identification of rare and potentially novel causal variants co-segregating with obesity. No coding variants were identified within MC4R and LEP. However, in LEPR eight coding variants were identified, of which two were synonymous, five were missense and one was a frame-shift mutation. Identified mutations were classified as potentially damaging, if they were: 1) non-synonymous; 2) rare in the general population with a minor allele frequency below $0.1 \%$ $[38,39]$ and 3 ) homozygous or if two or more heterozygous mutation were present within the same gene. Two identified variants fulfilled these criteria; one was a frame-shift variant (p.Ser1090Trpfs*6) and the other was a missense mutation (p.Pro892Arg). The pathogenicity of the missense variant was assessed using CADD scores [40].

\section{Frameshift mutation (Ser1090Trpfs*6)}

In family OB4, the novel homozygous frameshift mutation c.3260AG (p.Ser1090Trpfs*6) which truncates the LEPR protein, was identified in exon 20 of the $L E P R$ (Fig. 1). This frameshift was the result of a deletion of AG at nucleotide position $66,102,459$ to $66,102,461$. This mutation was located within the homozygosity region on chromosome $1 \mathrm{p} 31.1$ from position 55,397,406 to $75,241,971$. This homozygous region was only shared among affected family members.

Affected members in the family OB4, originating from the Rajanpur district of the Punjab province in Pakistan, had a very homogenous phenotype, comprising hyperphagia and rapid weight gain resulting in morbid obesity at an early age. This severe phenotype was evident in several affected family members, including two females (OB4-7 and OB4-8) aged 12 and 8 years, respectively, as well as two male first cousins (OB4-9 and OB4-10) aged 10 and 8 years, respectively. At the time of recruitment of the family, the proband OB4-7, aged 12 years, weighed $145.0 \mathrm{~kg}$ with a BMI SDS of 4.48 and BMI of $62.8 \mathrm{~kg} / \mathrm{m}^{2}$ (Table 1). At follow-up, the proband was 14 years old with pubertal stage of Tanner IV [41], yet, without menarche and had developed diabetes with C-peptide level of $0.92 \mathrm{nmol} / \mathrm{L}$. Moreover, the sibling (OB4-8) and two affected cousins (OB4-9, OB4-10) were in the pubertal stage of Tanner I [41, 42]. The severity of the mutation was evaluated based on the sex of the carriers, as a sex-specific effect of $L E P R$ mutations has previously been suggested [43]. However, we did not find any effect of the mutation influenced by the sex of the carriers (Table 2).

\section{Missense mutation (p.Pro892Arg)}

The novel missense mutation p.Pro892Arg, located in exon 20 in $L E P R$, was identified in proband OB25-4 of family OB25 (Fig. 2). This mutation was located at position $66,101,875$ within a homozygous region from position $59,653,630$ to $91,206,170$ on chromosome 1 p31. Born of a consanguineous marriage, the proband presented with a normal birth weight of $3.0 \mathrm{~kg}$ but after two months, she rapidly gained weight and attained the weight of $18.0 \mathrm{~kg}$ at the age of one year, corresponding to a BMI SDS of 6.49 (Table 1). In addition, the proband suffered from diabetes and displayed developmental delay. The proband was also in the pubertal stage of Tanner I. When annotated using online bioinformatics tools, p.Pro892Arg was predicted to be damaging and had CADD score of 28 , strongly suggesting the mutation to be deleterious. 


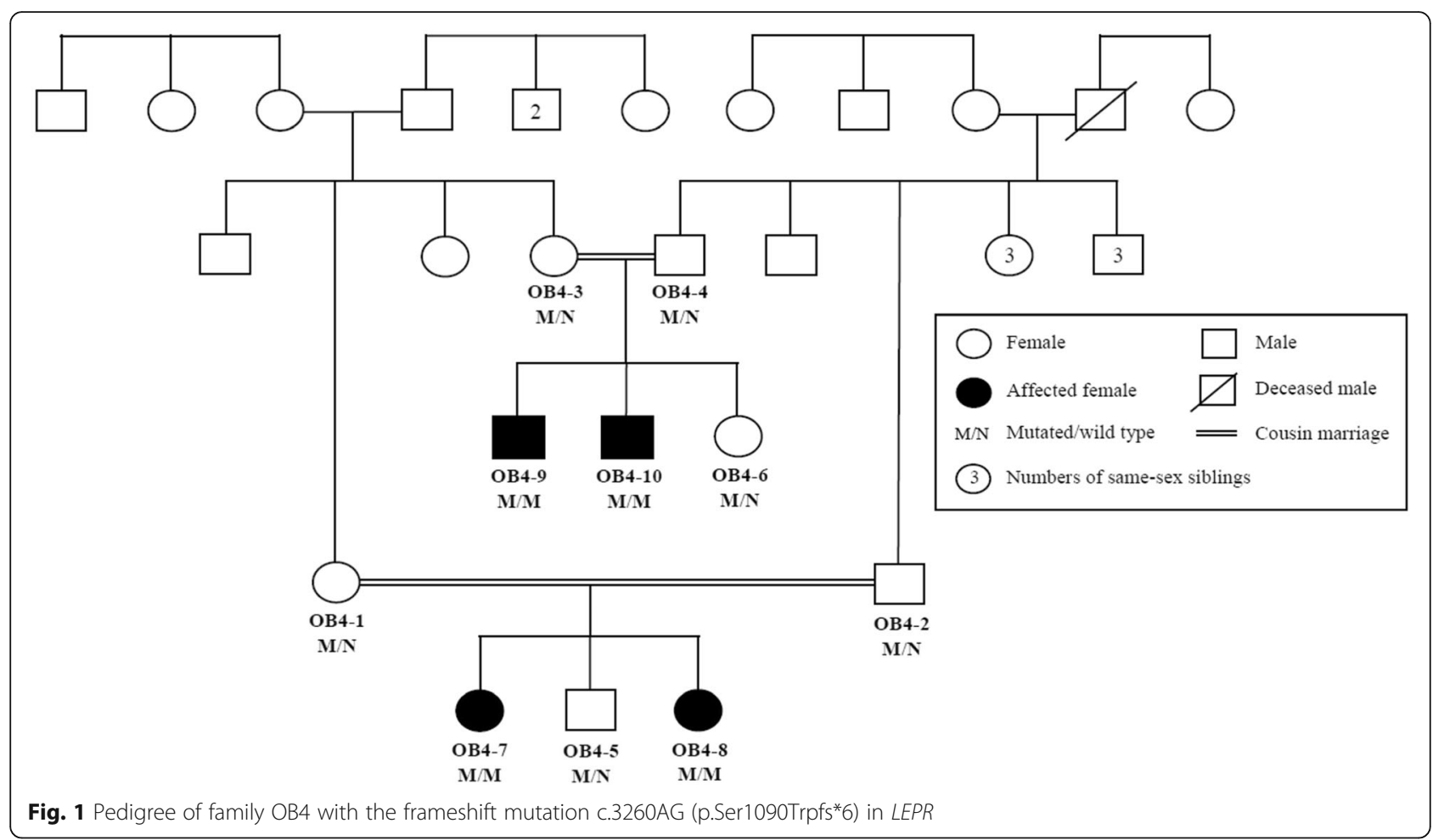

\section{Discussion}

In the present study, we employed targeted resequencing as a means to identify the genetic etiology in cases with severe early-onset obesity. The sequencing data was analyzed with respect to the three main genes known to be involved in monogenic forms of obesity, i.e. $L E P, L E P R$ and MC4R. Given the high prevalence of LEP, LEPR and $M C 4 R$ mutations previously reported in Pakistani populations [18], a similarly high prevalence of causal variants within these genes was expected. However, only two of the 25 examined probands carried homozygous recessive mutations, and both mutations were positioned in LEPR.
LEPR mutations have previously been reported to influence the risk of developing severe early-onset obesity, hypogonadotropic hypogonadism and hypothalamic hypothyroidism [24, 44], which is similar to the clinical characteristics of leptin deficiency [24]. Furthermore, in mice, Lepr mutations have been found to influence the susceptibility of type 2 diabetes [45]. Hypogonadotropic hypogonadism in LEPR-deficient individuals may be due to a defect both at the hypothalamic and the pituitary level [46]. However, hypogonadism may change over time, as in the case of spontaneous pubertal development and a natural pregnancy [24].

Table 1 Clinical characteristics of probands with homozygous LEPR mutations

\begin{tabular}{lll}
\hline & Proband OB4-7 & Proband OB25-4 \\
\hline Family ID & OB4 & OB25 \\
Sex & Female & Female \\
Age at enrolment (years) & 12.18 & 1.03 \\
Age at obesity onset & 40 days & 60 days \\
Height $(\mathrm{cm})$ & 152.0 & 76.2 \\
Weight $(\mathrm{kg})$ & 145.0 & 18.0 \\
BMI $\left(\mathrm{kg} / \mathrm{m}^{2}\right)$ & 62.8 & 31.0 \\
BMI SDS & 4.49 & 6.49 \\
Waist circumference $(\mathrm{cm})$ & 137.0 & 73.6 \\
Family history of obesity & No & No \\
Related co-morbidities & Diabetes & Diabetes, dyslipidaemia, hepatic and renal function disorder \\
Mutation type & Frameshift & Missense \\
\hline
\end{tabular}


Table 2 Sex stratified analysis of BMI, weight and waist of homozygous carriers of the LEPR p.Ser1090Trpfs*6 mutation in family OB4

\begin{tabular}{|c|c|c|c|c|}
\hline & BMI $\left(\mathrm{kg} / \mathrm{m}^{2}\right)$ & BMI SDS & Weight (kg) & Waist (cm) \\
\hline \multicolumn{5}{|c|}{ Female carriers } \\
\hline OB4-7 & 62.8 & 4.49 & 145.0 & 137.0 \\
\hline OB4-8 & 38.2 & 4.40 & 75.0 & 111.7 \\
\hline Mean (SD) & $50.5(17.4)$ & $4.44(0.062)$ & $110.0(49.5)$ & $124.4(17.9)$ \\
\hline \multicolumn{5}{|l|}{ Male carriers } \\
\hline OB4-9 & 40.8 & 4.18 & 80.2 & 111.7 \\
\hline OB4-10 & 41.0 & 5.39 & 55.0 & 99.0 \\
\hline Mean (SD) & $40.9(0.15)$ & $4.79(0.85)$ & $67.6(17.8)$ & $105.4(8.98)$ \\
\hline$p$-value* & 0.6 & 0.7 & 0.4 & 0.3 \\
\hline
\end{tabular}

*Evaluated using a t-test
Both of the novel LEPR mutations identified in the current study, are positioned in the intracellular domain of LepRb, which is involved in energy homeostasis, glucose metabolism, fertility, growth and the action of insulin $[47,48]$. Upon binding, leptin activates the LepRb through the mediation of multiple signaling pathways, including phosphorylation of cytoplasmic tyrosine kinases of Janus Kinase 2 (JAK2), conscription of signal transducer and activator of transcription 3 (STAT3) and mitogen-activated protein kinase (MAPK) cascade [47, 49-51]. In both humans and mice, multiple forms of LepRb are known, including short intracellular domain forms ranging from 32 to 40 amino acids and the long form comprising 303 amino acids, which is predominantly expressed in the hypothalamus [14, 48, 52-54]. The missense mutation (p.Pro892Arg), identified in a family OB25, is located in the Box 1 motif which is important both for leptin-dependent JAK2 activation through the mediation of signaling by the intracellular domain and for

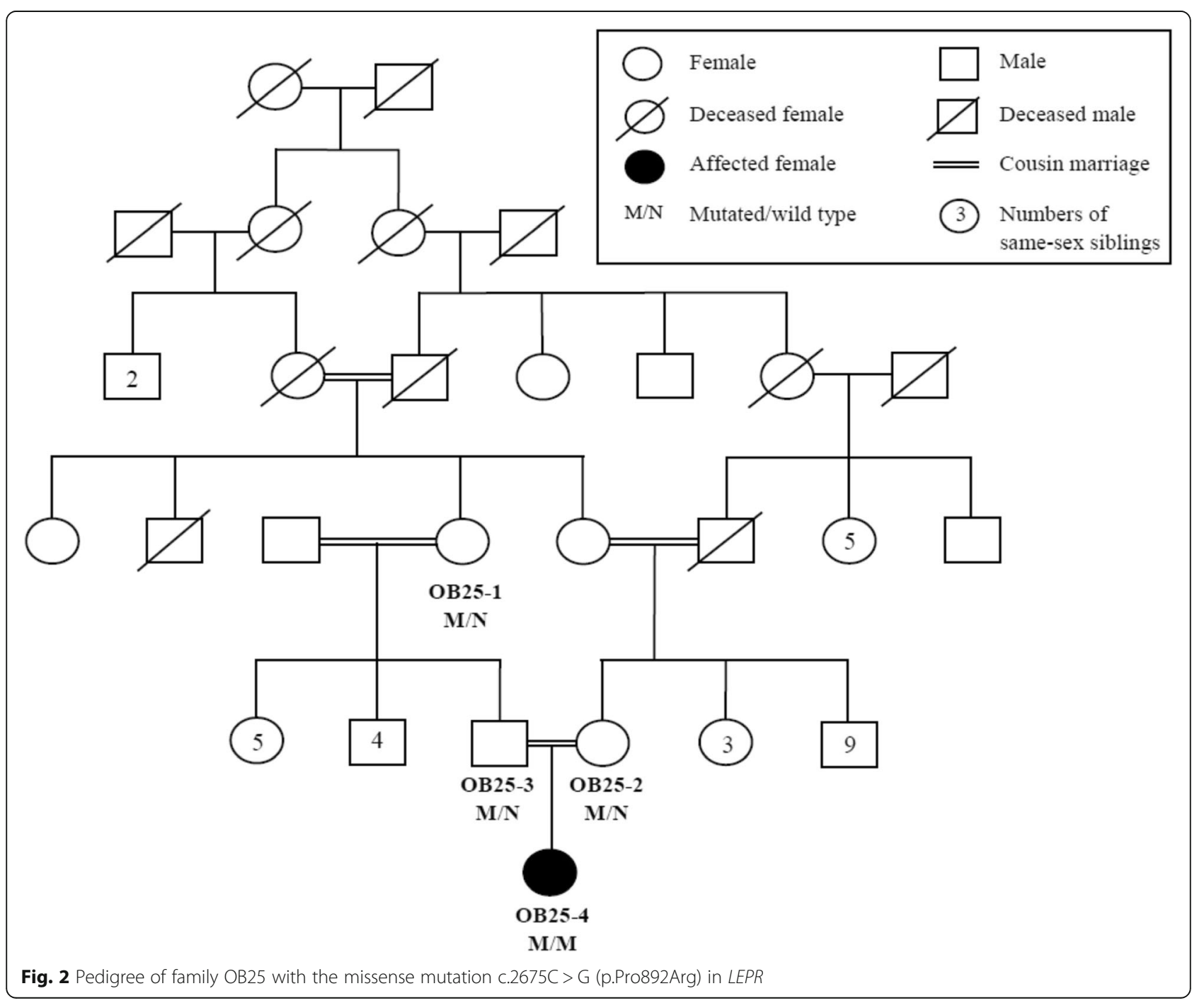


the physiologic actions of leptin $[52,55]$. The CADD score of the identified mutation (p.Pro892Arg) is 28, which indicates this is a very likely disease-causing variant. The second mutation, i.e. frameshift (Ser1090Trpfs*6) identified in the family OB4, is located in the long intracellular domain of LepRb and has sequence motifs resulting in the truncation of the domain, thereby suggesting a dysfunctional effect on its intracellular signal-transducing capabilities.

The highly deleterious nature of the identified two mutations (p.Pro892Arg and Ser1090Trpfs*6) is consistent with the clinical conditions of hyperphagia, rapid weight gain and extreme obesity observed in proband OB4-7. In both probands, the mutations were found in a homozygous state, and based on genotyping of family members, the homozygous region was found to be shared among affected individuals only, while parents of the probands were heterozygous carriers. Thus, when combined, our results strongly indicate that the identified mutations are causal.

Previously, it has been observed that boys in the Pakistani population are more prone to obesity than girls [56]. In addition, Iranian consanguineous families have revealed that LEPR deficiency may be more severe in females compared to males [43]. However, in OB4 where the mutation was found in both affected boys and girls, it showed the same level of severity irrespective of sex.

Increasing knowledge of genetic factors involved in the development of childhood obesity leads towards an improved understanding of the genetic etiology of this disorder. For this purpose the Pakistani population is unique due to its large size, its high number of families with known consanguineous marriages and the high frequency of large pedigrees [56]. Especially the identification of rare, damaging variants predisposing to obesity holds promise to the future development of novel therapeutic options and personalized medicine based on molecular diagnosis [24, 57]. In the case of congenital leptin deficiency caused by deleterious LEP mutations, hormonal leptin therapy has proved to have dramatic treatment effects, successfully decreasing the body weight and hyperphagia of the carriers $[58,59]$. Recently, treatment with mechanism-based therapy using a MC4R agonist (setmelanotide) in two patients with damaging pro-opiomelanocortin (POMC) mutations completely reversed hyperphagia and induced a remarkable weight loss while normalizing insulin sensitivity [60]. Albeit no effective drug therapies are currently available for LEPR deficient individuals, treatment of dysfunctional POMC with MC4R-agonist suggests its efficacy in other monogenic defects of the hypothalamic leptin-melanocortin pathway, including LEPR deficient patients [60]. Hence, the treatment with setmelanotide might be an effective in treatment of probands with non-functional LEPR, as identified in our study.
Yet, within 23 of the probands included in the present study, no causal variants were identified. For these remaining probands, the application of whole exome sequencing may be an important means to examine whether damaging mutations in other, yet unknown genes, may be the cause of their inherited early-onset obesity.

\section{Conclusion}

Using targeted resequencing in consanguineous Pakistani families, two novel mutations, including a frameshift and a missense mutation, were identified in probands with severe early-onset obesity. Both of these mutations were identified in a homozygous state. Our findings demonstrate the effectiveness of targeted resequencing to identify rare coding pathogenic mutations in consanguineous cases of severe early-onset obesity.

\section{Additional file}

Additional file 1: Clinical characteristics of 34 affected individuals in 25 families. (DOCX $33 \mathrm{~kb}$ )

\begin{abstract}
Abbreviations
BMI: Body mass index; CADD: Combined annotation dependent depletion; IIUI: International Islamic University Islamabad; JAK2: Janus Kinase 2; LEP: Leptin; LEPR: Leptin-receptor; MAPK: Mitogen-activated protein kinase; MC4R: Melanocortin 4 receptor; MSH: Melanocyte stimulating hormone; NGS: Next generation sequencing; OB: Obesity; PCA: Principal component analysis; PIMS: Pakistan Institute of Medical Sciences; POMC: Pro-

opiomelanocortin; QC: Quality control; SDS: Standard deviation score; SNP: Single nucleotide polymorphism; STAT3: Signal transducer and activator of transcription 3
\end{abstract}

\section{Acknowledgements}

The authors wish to thank the patients and their families for their involvement and cooperation in this study. The authors also wish to thank A. Forman, T. H. Lorentzen and G. J. Klavsen for laboratory assistance, G. Lademann for secretarial support and T.F. Toldsted for grant management (all from Novo Nordisk Foundation Center for Basic Metabolic Research, Section of Metabolic Genetics, Faculty of Health and Medical Sciences, University of Copenhagen).

\section{Funding}

This study was partially funded by the Higher Education Commission (HEC) of Pakistan by awarding IRSIP (Grant No: 1-8/HEC/HRD/2017/17326, PIN: IRSIP 35 BMS 26) to RKN and by the Novo Nordisk Foundation Center for Basic Metabolic Research, Faculty of Health Sciences, University of Copenhagen, Copenhagen, Denmark. This study is part of the TARGET (The impact of our genomes on individual treatment response in obese children, https://cbmr.ku.dk/research/human-genomics-and-metagenomics-inmetabolism/target/) and BIOCHILD (Genetics and systems biology of childhood obesity in India and Denmark, http://biochild.ku.dk) consortia studies, as well as The Danish Childhood Obesity Biobank. The Novo Nordisk Foundation Center for Basic Metabolic Research is an independent Research Center at the University of Copenhagen, partially funded by an unrestricted donation from the Novo Nordisk Foundation (www.metabol.ku.dk).

\section{Availability of data and materials}

The datasets generated and/or analyzed during the current study are not publicly available due to limitations in the consent form (consent has been given to study early-onset severe obesity), but are available from the corresponding author on reasonable request. 


\section{Authors' contributions}

RKN $, A P G, M H, N G, O P, C T H, A G$, and TH contributed to the conception and design of the study. GS and RKN examined and performed the clinical evaluation of the patients in each family. RKN prepared the genomic DNA samples, while $A U$ and WA provided assistance in preparation of genomic DNA samples. RKN, APG, MH, CTH and TH performed the analysis and did the interpretation of data. RKN drafted the article. All authors critically revised the manuscript and contributed to the discussion. The final version of the paper was read and approved by all authors.

\section{Ethics approval and consent to participate}

The current study protocol was approved by the local Ethical Committee with the name of 'Ethics Review Board (ERB) of Pakistan Institute of Medical Sciences (PIMS) at Shaheed Zulfiqar Ali Bhutto Medica University (SZABMU), Islamabad, Pakistan and the committee's reference number is No. F. 1-1/ 2015/ERB/SZABMU/-. The study was conducted in accordance with the guidelines of the Helsinki Declaration. Informed consent forms were obtained from individuals $>18$ years, while informed consent for individuals $<18$ years of age were given by parents or guardians.

\section{Consent for publication}

Written informed consent was obtained from the patients or their parents for the publication of their clinical and genetic data.

\section{Competing interests}

Wasim Ahmad is a member of the editorial board (Associate Editor) of BMC Medical Genetics. The remaining authors declare that they have no competing interests.

\section{Publisher's Note}

Springer Nature remains neutral with regard to jurisdictional claims in published maps and institutional affiliations.

\section{Author details}

'Department of Bioinformatics and Biotechnology, International Islamic University, Islamabad, Pakistan. ${ }^{2}$ Novo Nordisk Foundation Center for Basic Metabolic Research, Section of Metabolic Genetics, Faculty of Health and Medical Sciences, University of Copenhagen, Copenhagen, Denmark. ${ }^{3}$ Children Hospital, Pakistan Institute of Medical Sciences, Islamabad, Pakistan. ${ }^{4}$ Department of Biochemistry, Faculty of Biological Sciences, Quaid-i-Azam University, Islamabad, Pakistan.

\section{Received: 10 April 2018 Accepted: 25 October 2018}

\section{Published online: 15 November 2018}

\section{References}

1. Guh DP, Zhang W, Bansback N, Amarsi Z, Birmingham CL, Anis AH. The incidence of co-morbidities related to obesity and overweight: a systematic review and meta-analysis. BMC Public Health. 2009;9(0):88.

2. Malis C, Rasmussen EL, Poulsen P, Petersen I, Christensen K, BeckNielsen $\mathrm{H}$, Astrup A, Vaag AA. Total and regional fat distribution is strongly influenced by genetic factors in young and elderly twins. Obes Res. 2005;13(12):2139-45.

3. Marti A, Martinez-Gonzalez MA, Martinez JA. Interaction between genes and lifestyle factors on obesity. Proc Nutr Soc. 2008;67(1):1-8.

4. Moustafa JSE-S, Froguel P. From obesity genetics to the future of personalized obesity therapy. Nat Rev Endocrinol. 2013;9(7):402-13.

5. Walley AJ, Asher JE, Froguel P. The genetic contribution to non-syndromic human obesity. Nat Rev Genet. 2009;10(7):431-42.

6. O'Rahilly S, Faroogi I. Genetics of obesity. Philos Trans R Soc Lond Ser B Biol Sci. 2006;361(1471):1095-105

7. Ramachandrappa S, Faroogi IS. Genetic approaches to understanding human obesity. J Clin Invest. 2011;121(6):2080-6.

8. Stutzmann F, Vatin V, Cauchi S, Morandi A, Jouret B, Landt O, Tounian P, Levy-Marchal C, Buzzetti R, Pinelli L, et al. Non-synonymous polymorphisms in melanocortin- 4 receptor protect against obesity: the two facets of a Janus obesity gene. Hum Mol Genet. 2007;16(15):1837-44.

9. Hinney A, Bettecken T, Tarnow P, Brumm H, Reichwald K, Lichtner P, Scherag A, Nguyen TT, Schlumberger P, Rief W, et al. Prevalence, spectrum, and functional characterization of melanocortin- 4 receptor gene mutations in a representative population-based sample and obese adults from Germany. J Clin Endocrinol Metab. 2006;91(5):1761-9.

10. Gill R, Cheung YH, Shen Y, Lanzano P, Mirza NM, Ten S, Maclaren NK, Motaghedi R, Han JC, Yanovski JA, et al. Whole-exome sequencing identifies novel LEPR mutations in individuals with severe early onset obesity. Obesity (Silver Spring). 2014;22(2):576-84.

11. Bates SH, Myers MG Jr. The role of leptin receptor signaling in feeding and neuroendocrine function. Trends Endocrin Met. 2003;14(10):447-52.

12. Ronti T, Lupattelli G, Mannarino $E$. The endocrine function of adipose tissue: an update. Clin Endocrinol. 2006;64(4):355-65.

13. Saeed S, Bech PR, Hafeez T, Alam R, Falchi M, Ghatei MA, Bloom SR, Arslan $M$, Froguel P. Changes in levels of peripheral hormones controlling appetite are inconsistent with hyperphagia in leptin-deficient subjects. Endocrine. 2014;45(3):401-8.

14. Tartaglia LA, Dembski M, Weng X, Deng N, Culpepper J, Devos R, Richards GJ, Campfield LA, Clark FT, Deeds J, et al. Identification and expression cloning of a leptin receptor, OB-R. Cell. 1995;83(7):1263-71.

15. Fei H, Okano HJ, Li C, Lee GH, Zhao C, Darnell R, Friedman JM. Anatomic localization of alternatively spliced leptin receptors $(\mathrm{Ob}-\mathrm{R})$ in mouse brain and other tissues. Proc Natl Acad Sci U S A. 1997;94(13):7001-5.

16. Saeed S, Butt TA, Anwer M, Arslan M, Froguel P. High prevalence of leptin and melanocortin-4 receptor gene mutations in children with severe obesity from Pakistani consanguineous families. Mol Genet Met. 2012;106(1):121-6.

17. Saeed S, Bonnefond A, Manzoor J, Philippe J, Durand E, Arshad M, Sand O, Butt TA, Falchi M, Arslan M, et al. Novel LEPR mutations in obese Pakistani children identified by PCR-based enrichment and next generation sequencing. Obesity. 2014;22(4):1112-7.

18. Saeed S, Bonnefond A, Manzoor J, Shabir F, Ayesha H, Philippe J, Durand E, Crouch H, Sand O, Ali M, et al. Genetic variants in LEP, LEPR, and MC4R explain $30 \%$ of severe obesity in children from a consanguineous population. Obesity. 2015;23(8):1687-95.

19. Gantz I, Miwa H, Konda Y, Shimoto Y, Tashiro T, Watson SJ, DelValle J, Yamada T. Molecular cloning, expression, and gene localization of a fourth melanocortin receptor. J Biol Chem. 1993;268(20):15174-9.

20. Cole SA, Butte NF, Voruganti VS, Cai G, Haack K, Kent JW, Blangero J, Comuzzie AG, McPherson JD, Gibbs RA. Evidence that multiple genetic variants of MC4R play a functional role in the regulation of energy expenditure and appetite in Hispanic children. Am J Clin Nutr. 2010; 91(1):191-9.

21. Blakemore AIF, Froguel P. Is obesity our genetic legacy? J Clin Endocr Metab. 2008;93(11):s51-6.

22. Farooqi IS, Keogh JM, Yeo GS, Lank EJ, Cheetham T, O'Rahilly S. Clinical spectrum of obesity and mutations in the melanocortin 4 receptor gene. $\mathrm{N}$ Engl J Med. 2003;348(12):1085-95.

23. Stutzmann F, Tan K, Vatin V, Dina C, Jouret B, Tichet J, Balkau B, Potoczna N, Horber F, Rahilly $S$, et al. Prevalence of melanocortin-4 receptor deficiency in Europeans and their age-dependent penetrance in multigenerational pedigrees. Diabetes. 2008;57(9):2511-8.

24. Dubern B, Clement K. Leptin and leptin receptor-related monogenic obesity. Biochimie. 2012;94(10):2111-5.

25. Clément K, Vaisse C, Lahlou N, Cabrol S, Pelloux V, Cassuto D, Gourmelen M, Dina C, Chambaz J, Lacorte J-M, et al. A mutation in the human leptin receptor gene causes obesity and pituitary dysfunction. Nature. 1998:392:398-401.

26. Martinelli CE, Keogh JM, Greenfield JR, Henning E, van der Klaauw AA, Blackwood A, O'Rahilly S, Roelfsema F, Camacho-Hübner C, Pijl H, et al. Obesity due to Melanocortin 4 receptor (MC4R) deficiency is associated with increased linear growth and final height, fasting hyperinsulinemia, and incompletely suppressed growth hormone secretion. J Clin Endocr Metab. 2011;96(1):E181-8.

27. Lubrano-Berthelier C, Le Stunff C, Bougneres P, Vaisse C. A homozygous null mutation delineates the role of the melanocortin-4 receptor in humans. J Clin Endocrinol Metab. 2004;89(5):2028-32.

28. Melchior C, Schulz A, Windholz J, Kiess W, Schoneberg T, Korner A. Clinical and functional relevance of melanocortin-4 receptor variants in obese German children. Horm Res Paediatr. 2012;78(4):237-46.

29. Woods CG, Cox J, Springell K, Hampshire DJ, Mohamed MD, McKibbin M, Stern R, Raymond FL, Sandford R, Malik Sharif S, et al. Quantification of homozygosity in consanguineous individuals with autosomal recessive disease. Am J Hum Genet. 2006;78(5):889-96. 
30. Farooqi IS, O'Rahilly S. Mutations in ligands and receptors of the leptinmelanocortin pathway that lead to obesity. Nat Clin Pract Endocrinol Metab. 2008;4(10):569-77.

31. Froguel P, Blakemore Al. The power of the extreme in elucidating obesity. $\mathrm{N}$ Engl J Med. 2008;359(9):891-3.

32. Elliott AM, Radecki J, Moghis B, Li X, Kammesheidt A. Rapid detection of the ACMG/ACOG-recommended 23 CFTR disease-causing mutations using ion torrent semiconductor sequencing. J Biomol Tech. 2012;23(1):24-30.

33. Cole TJ, Green PJ. Smoothing reference centile curves: the LMS method and penalized likelihood. Stat Med. 1992;11(10):1305-19.

34. Butte NF, Garza C, de Onis M. Evaluation of the feasibility of international growth standards for school-aged children and adolescents. J Nutr. 2007; 137(1):153-7.

35. Sambrook J, Russell DW. Molecular cloning: a laboratory manual; preparation and analysis of eukaryotic genomic DNA. 3rd ed. New York: Cold Spring Harbor Laboratory Press; 2001

36. Gao R, Liu Y, Gjesing AP, Hollensted M, Wan X, He S, Pedersen O, Yi X, Wang J, Hansen $T$. Evaluation of a target region capture sequencing platform using monogenic diabetes as a study-model. BMC Genet. 2014;15(1):13.

37. Purcell S, Neale B, Todd-Brown K, Thomas L, Ferreira MA, Bender D, Maller J, Sklar P, de Bakker PI, Daly MJ, et al. PLINK: a tool set for whole-genome association and population-based linkage analyses. Am J Hum Genet. 2007; 81(3):559-75.

38. Lek M, Karczewski KJ, Minikel EV, Samocha KE, Banks E, Fennell T, O'DonnellLuria AH, Ware JS, Hill AJ, Cummings BB, et al. Analysis of protein-coding genetic variation in 60,706 humans. Nature. 2016;536(7616):285-91.

39. Altshuler DMDR, Abecasis GR, Bentley DR, Chakravarti A, Clark AG. A global reference for human genetic variation. Nature. 2015;526(7571):68-74.

40. Kircher M, Witten DM, Jain P, O'Roak BJ, Cooper GM, Shendure J. A general framework for estimating the relative pathogenicity of human genetic variants. Nat genetics. 2014;46(3):310-5.

41. Marshall WA, Tanner JM. Variations in pattern of pubertal changes in girls. Arch Dis Child. 1969;44(235):291-303.

42. Marshall WA, Tanner JM. Variations in the pattern of pubertal changes in boys. Arch Dis Child. 1970;45(239):13-23.

43. Dehghani MR, Mehrjardi MYV, Dilaver N, Tajamolian M, Enayati S, Ebrahimi P, Amoli MM, Farooqi S, Maroofian R. Potential role of gender specific effect of leptin receptor deficiency in an extended consanguineous family with severe early-onset obesity. Eur J Med Genet. 2018.

44. Faroogi IS, Wangensteen T, Collins S, Kimber W, Matarese G, Keogh JM, Lank E, Bottomley B, Lopez-Fernandez J, Ferraz-Amaro I, et al. Clinical and molecular genetic spectrum of congenital deficiency of the leptin receptor. New Engl J Med. 2007;356(3):237-47.

45. Herberg L, Coleman DL. Laboratory animals exhibiting obesity and diabetes syndromes. Metabolism. 1977;26(1):59-99.

46. Hannema SE, Wit JM, Houdijk MECAM, van Haeringen A, Bik EC, Verkerk AJMH, Uitterlinden AG, Kant SG, Oostdijk W, Bakker E, et al. Novel leptin receptor mutations identified in two girls with severe obesity are associated with increased bone mineral density. Horm Res Paediatr. 2016:85(6):412-20.

47. Allison MB, Myers MG. Connecting leptin signaling to biological function. J Endocrinol. 2014;223(1):T25-35.

48. Cioffi JA, Shafer AW, Zupancic TJ, Smith-Gbur J, Mikhail A, Platika D, Snodgrass HR. Novel B219/OB receptor isoforms: possible role of leptin in hematopoiesis and reproduction. Nat Med. 1996;2(5):585-9.

49. Chua SC Jr, Chung WK, Wu-Peng XS, Zhang Y, Liu SM, Tartaglia L, Leibel RL. Phenotypes of mouse diabetes and rat fatty due to mutations in the $\mathrm{OB}$ (leptin) receptor. Science. 1996;271(5251):994-6.

50. Chua SC Jr, Koutras IK, Han L, Liu SM, Kay J, Young SJ, Chung WK, Leibel RL. Fine structure of the murine leptin receptor gene: splice site suppression is required to form two alternatively spliced transcripts. Genomics. 1997;45(2):264-70.

51. Tartaglia LA. The leptin receptor. J Biol Chem. 1997;272(10):6093-6.

52. Bjorbaek C, Uotani S, da Silva B, Flier JS. Divergent signaling capacities of the long and short isoforms of the leptin receptor. J Biol Chem. 1997; 272(51):32686-95

53. Chen H, Charlat O, Tartaglia LA, Woolf EA, Weng X, Ellis SJ, Lakey ND, Culpepper J, Moore KJ, Breitbart RE, et al. Evidence that the diabetes gene encodes the leptin receptor: identification of a mutation in the leptin receptor gene in db/db mice. Cell. 1996;84(3):491-5.

54. Lee GH, Proenca R, Montez JM, Carroll KM, Darvishzadeh JG, Lee Jl, Friedman JM. Abnormal splicing of the leptin receptor in diabetic mice. Nature. 1996;379(6566):632-5.
55. Kloek C, Haq AK, Dunn SL, Lavery HJ, Banks AS, Myers MG Jr. Regulation of Jak kinases by intracellular leptin receptor sequences. J Biol Chem. 2002 277(44):41547-55

56. Pigeyre M, Saqlain M, Turcotte M, Raja GK, Meyre D. Obesity genetics: insights from the Pakistani population. Obes Rev. 2018;19(3):364-80.

57. Ichihara S, Yamada Y. Genetic factors for human obesity. Cell Mol Life Sci. 2008;65(7-8):1086-98

58. Wabitsch M, Funcke JB, Lennerz B, Kuhnle-Krahl U, Lahr G, Debatin KM, Vatter P, Gierschik P, Moepps B, Fischer-Posovszky P. Biologically inactive leptin and early-onset extreme obesity. N Engl J Med. 2015;372(1):48-54

59. Faroogi IS, Matarese G, Lord GM, Keogh JM, Lawrence E, Agwu C, Sanna V, Jebb SA, Perna F, Fontana S, et al. Beneficial effects of leptin on obesity, $T$ cell hyporesponsiveness, and neuroendocrine/metabolic dysfunction of human congenital leptin deficiency. J Clin Invest. 2002;110(8):1093-103.

60. Kuhnen P, Clement K, Wiegand S, Blankenstein O, Gottesdiener K, Martini LL, Mai K, Blume-Peytavi U, Gruters A, Krude H. Proopiomelanocortin deficiency treated with a melanocortin-4 receptor agonist. New Engl J Med. 2016; 375(3):240-6.
Ready to submit your research? Choose BMC and benefit from:

- fast, convenient online submission

- thorough peer review by experienced researchers in your field

- rapid publication on acceptance

- support for research data, including large and complex data types

- gold Open Access which fosters wider collaboration and increased citations

- maximum visibility for your research: over $100 \mathrm{M}$ website views per year

At BMC, research is always in progress.

Learn more biomedcentral.com/submissions 